\title{
SELECTED FORMS OF ACTIVITY OF THE FOREIGN AFFAIRS COMMITTEE OF THE SEJM AND THE MAIN DIRECTIONS OF POLISH FOREIGN POLICY
}

\author{
WYBRANE FORMY AKTYWNOŚCI KOMISJI SPRAW \\ ZAGRANICZNYCH SEJMU A GŁÓWNE KIERUNKI POLSKIEJ \\ POLITYKI ZAGRANICZNEJ
}

Piotr Pochyły* (1)

\begin{abstract}
The article analyzes selected activities of the Foreign Affairs Committee of the Sejm of the Republic of Poland in connection with the main directions of Polish foreign policy. For the purpose of consideration of the thesis, it was assumed that the Foreign Affairs Committee has a complementary/supplementary role in the control of the directions of Polish foreign policy, and in Poland there was a balance between executive and legislative power in this area. The research problem was to determine the scale of the Committee's interest in world events through a specific response and to define the specific geographic area that would result from this activity. The method of quantitative analysis was used, PS Imago Pro 7.0 program was used for the research. The result of the research allowed to draw conclusions that the Committee's interest of opinion-forming and intervention through the publication of statements, as well as formulating recommendations in the vast majority is mani-
\end{abstract}

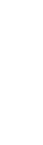


fested in relation to the most important issues in the immediate environment of Poland: Belarus, the situation of Poles in Lithuania, the events in the Caucasus, which is consistent with the basic directions of Polish foreign policy.

Keywords: Polish foreign policy; foreign affairs committee; Belarus; Grzegorz Schetyna; legislature; executive power
Białoruś, Polacy na Litwie, Kaukaz, co jest zgodne z podstawowymi kierunkami polskiej polityki zagranicznej.

Słowa kluczowe: polska polityka zagraniczna; komisja spraw zagranicznych; Białoruś; Grzegorz Schetyna; władza ustawodawcza; władza wykonawcza

\section{INTRODUCTION}

The purpose of this article is to analyze the way and scope of reaction of the Foreign Affairs Committee of the Sejm to the problems of Polish foreign policy through the formulation of a position, resolution, opinion, appeal or initiation of a resolution of the Sejm on international affairs and the activities of committee chairman in meetings with stakeholders. The research problem will be to determine the scale of the Committee's interest in world events through a specific reaction and to define a specific geographical area that will result from this activity.

The analysis covers the work of the Foreign Affairs Committee of the Sejm in the $7^{\text {th }}$ and $8^{\text {th }}$ parliamentary terms (2011-2019), i.e., at the moment when the full term of the Polish Sejm began after Poland's accession to the EU, and throughout this period either Law and Justice or Civic Platform held sway over Polish foreign policy - the chairman of the committee was always a politician from one or the other party.

The analysis was based on available materials from the website sejm.gov.pl. Accepted thesis: The Foreign Affairs Committee plays a complementary role in controlling the directions of Polish foreign policy (especially towards the eastern neighbors or the situation in the Caucasus), and in Poland there has been a balance between the executive and legislative power in this respect.

There are a number of works treating of the role and scope of participation of the legislature in the creation and inspiration of foreign policy (Malamud \& Stavridis, 2011; Tayie \& Dashti, 2018; Kesgin \& Kaarbo, 2010), especially observing the specifics of the functioning of the European Parliament and the influence of this institution on EU foreign policy (Bajtay, 2015), but also the pursuit of consensus within the state between the executive and legislative branches in 
terms of foreign policy principals (Raunio \& Wagner, 2017). The second popular aspect addressed regarding the role of the legislature in foreign policy is the activity called parliamentary diplomacy and the use of MPs in state foreign policy (Surmacz \& Kuczyńska-Zonik, 2019; Onderco, 2018; Jaskiernia, 2013).

A number of analyses of the work of the Sejm's Foreign Affairs Committee has been published, regarding the nature of its activities (Jaskiernia, 2004), its functioning in a specific period (Podgórzańska, 2007), work on specific directions of foreign policy (Podgórzańska, 2006), specific initiatives (Dudek, 2013), analysis of thematic debates (Góra, Łabędź, Pochyły, 2019, pp. 105-154). Partial studies on the work of the Committee can also be found in monographs on a wider range of topics (Dudek, 2019, pp. 264-292; Habowski, 2019, pp. 231-292).

If the Committee is interested in a certain issue, wants to draw the attention of the government, international institutions, or international public opinion to a given matter, or speak out on it, it has several instruments at its disposal. It can initiate a resolution of the Sejm by preparing and presenting its draft (lobbying for its adoption by the Sejm, preferably by acclamation), present a position or an appeal, issue a petition to a particular minister or the entire Council of Ministers, to which it must reply within 30 days as a standard rule. The possibilities are limited, but they make it possible, if skillfully used, to mark the position of the committee and the legislature itself in the process of debate on foreign policy and the shaping of Poland's position on the issue.

\section{POSITION AND COMPETENCES OF THE FOREIGN AFFAIRS COMMITTEE OF THE SEJM}

There are three basic functions of the Polish Sejm: legislative, controlling, and creative. Within their framework the parliamentary committees fulfill primarily the first two (Jaskiernia, 2004, p. 42). An important element of fulfilling these duties by the parliament is the activity of parliamentary committees called the "heart" of the Sejm. Their work allows for preparing and giving opinions on the content of laws, resolutions, exercising control over the government by formulating interpellations, questions and inquiries, listening to the information of the council of ministers or individual ministers, including first of all the annual information of the Minister of Foreign Affairs on the directions of foreign policy (Kuciński, 2017, pp. 20-22, 26-35). Within the control function, the following can be distinguished: the right of information, the right of presence, the right 
of hearing and inspiration (Juchniewicz, 2013, pp. 18-19). In addition to the standard parliamentary work related to giving an opinion on Poland's ratification of international agreements or exercising the control function, there are possibilities to influence, e.g., the way of thinking and forcing the actions of the Minister of Foreign Affairs, by: a) asking for information from the Minister on a specific current event, the direction of policy towards a selected geographical area or some international organization (EU), the personnel policy of the Ministry of Foreign Affairs; b) listening to the theses of the annual exposé of the Minister of Foreign Affairs on the directions of Polish foreign policy, when it is possible - to exchange views, draw the Minister's attention to a specific issue, ask for explanations. The day before the plenary speech, the Minister presents the basic theses to the Committee. The distinction is the result of many years of practice, respected by successive governments. Members, in return for this privilege, are obliged to keep the contents of the theses secret until the following day. The minister answers questions, listens to opinions, but most often has little time and this is done in a hurry (Petny zapis..., 2014, pp. 3-4, 6, 10)' , but each time such a meeting occurs. There is no voting, expressions of approval or disapproval, but a simple exchange of views. A different rank is held by the presentation of an exposé on the parliamentary forum, when the speech lasts for tens of minutes to an hour, deputies inundate the minister with dozens of questions, and at the end a vote of no confidence in the minister is held. This takes place in the middle debate, which lasts 240 minutes. The effort for the entire ministry involving this day was described in detail by Minister Radosław Sikorski in his memoirs (Sikorski, 2018, pp. 79-87).

The scope of the work of the Committee outlined in the Rules of Procedure of the Sejm - "The scope of the Committee includes matters of national foreign policy" (Regulamin Sejmu RP [Rules of Procedure of the Sejm], 2012, p. 81) - is, on the one hand, precise but, on the other hand, generates a huge number of matters and issues that become the subject of the work and interest of the Committee. The competences and tasks of the Foreign Affairs Committee of the Sejm

\footnotetext{
1 Radosław Sikorski as the Minister of Foreign Affairs said that he would work on the final version of his speech at night, make corrections and that is why he limited himself to the basic theses. Each time he chose the main topic - the axis of the speech, which resulted in situations when during the Commission's deliberations he was asked why he would not speak about the Polish vision of the European Union. He stated that nothing had changed in these matters, and he had said so in previous years (see: Pelny zapis..., pp. 3-4, 6, 10).
} 
are clarified through the implementation of Chapter 8 of the Rules of Procedure of the Sejm (Proceedings with the notification of the Prime Minister on the intention to submit to the President for ratification an international agreement whose ratification does not require consent expressed in an act), and some of the activities result indirectly from a number of acts: on foreign service of July 27, 2001, on international agreements of April 14, 2000, and on development cooperation of September 16, 2011. However, as Chairman Tyszkiewicz states in the 2015 report, "The actual catalog of topics dealt with by the Foreign Affairs Committee in the $7^{\text {th }}$ term was expanded to include matters arising from the customs and practice of the Sejm, decisions of the Speaker and the Presidium of the Sejm, and actions taken by the leadership of the Committee in response to current events in the area of state foreign policy. On several occasions, sittings were also convened at the request of members of the Committee, in accordance with Article 152(2) of the Rules of Procedure of the Sejm (session No. 37, 51, 55, 166)" (Sprawozdanie Komisji Spraw Zagranicznych, Część opisowa, 2015, pp. 4-5).

The status of the Foreign Affairs Committee of the Sejm in comparison with other committees is characterized by specificity in position and operation. Although it is a medium-sized committee in terms of numbers, it is considered prestigious. Its distinguishing feature is the fact that its chairman has a separate cabinet, which is not the norm at the Polish Sejm due to its architectural limitations. This serves as a dignified reception of foreign delegations, appropriate for diplomatic canons and dignity of matters of interest to parliamentarians from other countries, representatives of governments, international institutions, special guests. The final report on the work of the Committee for 2011-2015 shows that out of 135 visits as many as 75 times the chairman of the Committee met with guests alone, many times his deputy, only occasionally the meetings were held in a wider circle, such as the Bureau of the Committee or as part of the deliberations of the full Committee - only 3 times (Sprawozdanie Komisji Spraw Zagranicznych..., Table 18,2015). The same was true in the following term, when out of 116 visits, only 4 took place through a meeting with the full Commission - exclusively parliamentary delegations (Albania, Canada, China, Belarusian opposition) (Sprawozdanie Komisji Spraw Zagranicznych..., Table 19, 2019). In total, in the two terms of office, $61.8 \%$ of all visits can be distinguished as stand-alone meetings of the President and $21.5 \%$ of situations where the guest(s) were received only by the Deputy Chairman. Adding to this $5.2 \%$ of meetings involving the committee's bureau, we obtain a total of $88 \%$ of all visits when representatives of the committee's governing body represented the committee in 
such relationships. This allows us to draw a conclusion that, first of all, the fact who chairs the committee is important not only in terms of regulating its work, planning its debates and conducting them, but this function makes it possible to actively participate in the debate on foreign policy and exchange views, to refer, as it were, to Polish foreign policy on behalf of the Republic without the presence of a representative of the Polish government. This conclusion becomes more meaningful if we mention the accusations made against the chairman of the committee in 2015-2019, Grzegorz Schetyna, coming from the opposition Civic Platform party, by the committee member Witold Waszczykowski from the Law and Justice party - former foreign minister in the years 2015-2017. He argued that Schetyna goes beyond the framework of the function and during meetings in his office and official foreign visits as chairman of the parliamentary committee he presents his own vision of foreign policy, contradicting the government's principals: "It is a mistake to keep him in the position of head of the Foreign Affairs Committee, because he uses this function to show the world that there is some alternative diplomacy" (Zaremba, 2018). The division of power over committees in the Sejm is based on the position of parliamentary clubs, but Jarosław Kaczyński's agreement to entrust the chairmanship of a committee with international activities to Grzegorz Schetyna remains an unexplained mystery, although the Civic Coalition club had to get some committees by virtue of its size (134 seats out of 460 possible), and Schetyna was the then chairman of the Civic Platform - the largest grouping in the coalition, so he could negotiate the chairmanship of a committee of his interest ${ }^{2}$.

Chairman Schetyna's official international activity closed in on 7 foreign visits (including only two in which he was the only outgoing member) out of a total of 30 recorded under committee's activity (Wyjazdy zagraniczne przedstawicieli komisji..., 2019). Taking into account that in the $7^{\text {th }}$ term, which he did not finish as chairman as he took over as foreign minister in September 2014, he made 15 visits in three years out of a total of 49 recorded within the committee (Wyjazdy zagraniczne przedstawicieli komisji..., 2015), this activity during his time as

${ }^{2}$ A separate issue, impossible to confirm, is the fact that Jarosław Kaczyński does not attach much importance to foreign policy, and certainly to carrying it out in accordance with the constitutional division (the marginalization after 2015 of the role of the Ministry of Foreign Affairs, the transfer of some competencies to the Presidential Palace in the field of relations with the U.S. or security issues, consent to the creation of the Office of International Policy of the President of Poland as another center for the creation of foreign policy of the state, the transfer of matters related to the European Union to the Prime Minister's Office). 
chairman of the committee being in opposition to the government cannot be recorded as overly foreign active in this dimension. A greater role should be attributed to the parliamentary activity, as in the term 2015-2019 he received as much as $71.5 \%$ of visits to committees on his own. This is a significant increase if it is compared with the previous term, when for the whole chairman (function) - counting together with Robert Tyszkiewicz's holding of the function from September 2014 until the end of the term - he held 55.5\% of the meetings by himself, but counting the period of Grzegorz Schetyna's holding of the function (until September 22, 2014), it was $69 \%$ of the total committee meetings, so a statistically insignificant difference $(71.5 \%$ vs. $69 \%)$. It can be concluded that, on the one hand, this was due to the nature of the function and Grzegorz Schetyna's appropriate approach to the duties of his post, when he did not cede his duties to any of his deputies, but also that he was eager to meet the guests himself in order to have the opportunity, in the usually very busy calendar of meetings of a guest in Warsaw, to personally discuss bilateral relations in his way of perceiving foreign policy. While between 2011 and 2014 the government was co-founded by the Civic Platform and the problem of a potentially different view of foreign policy principals did not exist, from late 2015 onwards this may have been a temptation for the committee chairman to be somewhat independent in external relations and to distance himself from the directions covered by the United Right government.

The analyses presented here concern an exhaustive sample, i.e., all visits of parliamentary delegations and representatives of governments, institutions and foreign organizations in the years 2011-2019. The analyses took into account the following variables - country(ies) represented by members of the delegation (representatives of selected foreign institutions and organizations), declared purpose of the visit, month and year when the visit took place and a variable regarding information on who from the Commission hosted a given delegation (representatives of selected foreign institutions and organizations). In order to correctly analyze collected data, it became necessary to create an additional variable, which was based on variables related to the nature of visit and composition of delegation. The new variable made it possible to aggregate individual visits into three groups:

Group I - representatives of the Diplomatic Corps accredited in Poland;

Group II - representatives of governments, executive power (ministers, secretaries, advisors to governments or ministers); 
Group III - parliamentary delegations, presidents of parliaments, journalists, foreign non-parliamentary opposition, lobbyists.

Distinguishing these types of visits allows for a more comprehensive analysis of the nature of meetings, their number and dates on which they took place. At the same time, the new variable allows us to analyze visits in the context of person(s) hosting delegations (representatives of selected foreign institutions and organizations) as representatives of the Polish side. Taking this context into account seems to be crucial for a proper assessment of the functioning and division of tasks in the Commission as well as for the application of the adequacy of formal empowerment of the Polish delegation in relation to the reception of foreign delegation. All analyses were carried out using PS Imago Pro 7.0 statistical software.

The purpose of this procedure was to draw conclusions about the nature of the meetings and to distinguish the most important political groups interested in cooperation with the Committee and in learning about the foreign policy vision of its chairman, as well as to observe the trend as to the extent to which contacts with the Committee were important for the representatives of the foreign executive, not through the ambassador or embassy counsellor (probing the parliamentarians is their duty), as this would be standard practice, but precisely the ministers or secretaries of state who saw the sense and need for such a meeting. The research has shown that over the past 8 years, meetings in groups I and III have prevailed (in total over $83 \%$ of all meetings), so group II can be considered insignificant in this criterion. There is a slight predominance of group I meetings over group III meetings, which on the one hand can be regarded as an insignificant difference (5.6\%), but on the other, also indicates that the possibility to consult with the chairman of the committee, who usually receives such guests, is important to the Diplomatic Corps. It seems valuable to note that this nature of meetings - discussing bilateral relations with a specific ambassador, when analyzing the work of the committee from the $9^{\text {th }}$ term of the Sejm (from 2019 onwards), will require a different approach, as the committee has taken over the practice previously followed by the Senate Foreign and European Union Affairs Committee and invites information on European affairs from the ambassador of the country that assumes or ceases to hold the Presidency of the Council of the European Union in a given six-month period. Such meetings take place in the deliberations of the entire committee, so the ratio of meetings and their purpose - a departure from the standard discussion of bilateral relations often combined with the usual visit of the ambassador who has just taken up his post 
in Warsaw and comes to meet with the chairman of the committee - will be of a different nature looking at the period 2019-2023 than in the period under review, i.e., 2011-2019. It will have to be considered on two levels - the maintenance of meetings with ambassadors from all over the world (almost always only in a narrow circle), as well as official, assumed in the bi-annual work plans of the commission, meetings with the ambassadors of EU countries, i.e., only from the European circle, but subject to publicity through television broadcasting of the meeting and publication of transcripts of the proceedings.

The quantitative analysis of the list of meetings for the years 2011-2019, in which only the chairman of the committee himself participated, allows to conclude that they met first of all with representatives of the diplomatic corps accredited in Warsaw $-44.6 \%$ of the meetings included in the reports for the years 2011-2019, but also with representatives of the executive power in rank, ministers and deputy ministers (16.3\% of the meetings, primarily of the chairman of the committee with this type of guests). 39\% of meetings concerned representatives of parliamentary delegations and various types of guests (nonparliamentary oppositionists, journalists, associations). In addition to strictly parliamentary activities, members of the committee, especially its chairman, carried out extensive political activities and actively participated in the diplomatic process. It is also important to pay attention to the rank of guests and which countries they come from. Even if the frequency of meetings is not significant it is worth noting the rank due to the origin and function of the guest(s). In 2015-2019, for example, these were the U.S. State Department's Sanctions Coordinator (Ukraine, Iran), the Foreign Ministers of Germany, France, Croatia, Macedonia, Hungary, Finland, the U.S. Assistant Secretary of State, or the Minister for European Integration of Georgia. Generally, the committee Chairman or Presidium met with policy makers from areas of direct interest to Polish diplomacy (Poland's neighbors, EU members, or the United States), and these consultations served at least two functions for committee guests: to maintain bilateral relations and to develop channels of consultation for policy directions.

The second important symptom of the Committee's activity is the fact that it has the initiative, can pass and publish official opinions, resolutions, desiderata and positions, which can have an international and opinion-forming range, go beyond the framework of the control function of the Sejm over the government, and above all, over the Ministry of Foreign Affairs. As it could be heard during the debates, its members were aware that they could express something more bluntly, while the government was not supposed to, e.g., in the case of Tibet for fear of 
consequences for the Polish-Chinese relations. The Committee could take it upon itself to express opinions, as it were, formally on behalf of Poland, but at the same time "not tying the hands" of the government, which had to conduct relations with such an important partner - e.g., in the descriptive part of the report of the $7^{\text {th }}$ term of the Sejm (2011-2015), chairman Robert Tyszkiewicz wrote that the visit of the Presidium of the Committee to Taiwan on December 16-20, 2013, "provided an opportunity to meet with the most important Taiwanese politicians, including the President of Taiwan, which, in the absence of official diplomatic relations with Taiwan and respecting the principle of 'one China', allowed to show and maintain Poland's interest in cooperation with this economically very important region" (Sprawozdanie Komisji Spraw Zagranicznych, Część opisowa, 2015, p. 12) $)^{3}$.

In the author's opinion, the use of a ploy with the economic nature of the visit was a cover-up, an obfuscation of the message that did not allow to make an official accusation of Poland's violation of the "one China" principle, but anyone familiar with the reality understands that while maintaining economic relations, political relations were also discussed, and economic relations are a part of foreign policy. By the way, the Bureau received an official invitation to pay the aforementioned visit to Taipei on October 22, 2013 from the Taipei Vice-Minister of Foreign Affairs Vanessa Yea-Ping (yet another proof of the non-economic aspect of relations), and not from the semi-officially operating in Warsaw director of the Taipei Economic and Cultural Office in Poland (since August 1 it has been operating under the name of Taipei Representative Office in Poland), whom we can consider as an informal ambassador of Taipei to Poland. Besides, a Polish-Taiwanese parliamentary group was appointed in successive terms of the Sejm. For Poland, Taiwan is one of the most important economic partners in Asia, at the end of the second decade of the $21^{\text {st }}$ century the value of mutual economic exchange amounted to 6-6.5 billion PLN per year (Mały Rocznik Statystyczny Polski, 2020, p. 337).

It happens that the Chairman of the Committee forces his candidate for ambassador and the Foreign Minister agrees, as confirmed by Radosław Sikorski (2018, p. 265). Another distinction, an emphasis on the special position of the Committee, is the fact that the opinion on the candidate for ambassador is not subject to further proceedings in the Sejm during the plenary session - the opinion of the Committee is binding, and it is sent to the Ministry of Foreign

\footnotetext{
${ }^{3}$ In the following pages of this article the forms of reaction will be discussed in more detail.
} 
Affairs without the mediation of the Speaker of the Sejm (his Chancellery). As a rule, communication through the Chancellery of the Sejm is a normal practice in the relations between the executive and legislative branches, and in this case we have an exception ennobling the Committee.

\section{SELECTED FORMS OF ACTIVITY OF THE FOREIGN AFFAIRS COMMITTEE}

One of the basic ways for the committee to address an important issue is to formulate a statement. It is a way to express views on issues that are important from the Polish point of view, most often international issues or issues that affect Polish foreign policy and its image. For example, on August 24, 2006, the Committee formulated a statement (there were no comments to the draft text proposed by the subcommittee) criticizing the Acting Undersecretary of State at the Ministry of Defense, Antoni Macierewicz, for accusing the majority of former foreign ministers in the Third Republic of Poland of serving a foreign intelligence service (he used the expression "agents of the Soviet secret services") ${ }^{4}$, which, in the opinion of the members of the Committee, undermined the foreign policy of recent years and damaged the image of Poland. A quick explanation of the case was expected (Stanowisko Komisji Spraw Zagranicznych..., 2006). Two issues are worth mentioning: first, the statement was signed by Committee Chairman Paweł Zalewski (this could have been done by a deputy chairman from an opposition party) - at that time a member of the Law and Justice club, and its content was elaborated by a subcommittee specially appointed at the request of deputy Marian Piłka, also at that time a member of the Law and Justice party. A year later, Paweł Zalewski was briefly suspended by Law and Justice President Jarosław Kaczyński for criticizing the foreign policy of the Ministry of Foreign Affairs, which was headed by Anna Fotyga, and Piłka left PiS together with the outgoing Speaker of the Sejm Marek Jurek and founded the Right of the Republic, but apart from them, other the Law and Justice deputies supported this unanimous statement. As deputy Tadeusz Iwiński of the Democratic Left

${ }^{4}$ After a request for clarification from the opposition, the coalition partners: League of Polish Families and Self-Defense, the Foreign Affairs Committee and the Minister of National Defense, Radosław Sikorski, Antoni Macierewicz apologized for using a "mental shortcut" when thinking about the communist period and not the Third Republic of Poland. 
Alliance (SLD) stated: "I would like to express my belief that this may be a good way to return to a situation in which consensus prevailed in matters concerning Polish foreign policy. Reaching an agreement on the wording of this text is an important event in this turbulent moment. May similar steps be taken in the future" (Petny, 2006, p. 3).

The second important issue is that the statement was created in response to the actions of the Undersecretary of State in the Ministry of Defense, not Foreign Affairs $^{5}$. This is an important issue in view of the control function exercised by parliament, including committees corresponding in name to existing ministries - the so-called departmental committees (parliamentary committees are usually more numerous than ministries and practical control is not always as clear as in the case of the Foreign Affairs Committee or the National Defense Committee), but in this case the importance of the matter - undermining the credibility and loyalty to the state of previous ministers of foreign affairs created a situation that forced the committee to react. The reaction to the words of Antoni Macierewicz was in line with the tasks set before it, but only in terms of foreign policy implications and not the sources of knowledge of Antoni Macierewicz or the motives that guided him during the interview ${ }^{6}$. Noteworthy in the case of Minister Macierewicz is the fact, which is often emphasized, that the Foreign Affairs Committee of the Sejm, dealing with such a sensitive part of state policy, is often able to work across party lines, in the name of the Polish raison d'état.

In the $8^{\text {th }}$ term of the Sejm (2015-2019), four positions were prepared, three were on Belarus and one on Georgia. While the positions on Belarus (as many as three during eighteen months) concerned opinions on political crises in that country, support for civil society, the position on Polish-Georgian relations supported mutual relations, not refraining from pointing out difficult issues (admonition to respect the judgment of the European Court of Human Rights

5 The National Defense Committee, which in principle supervises the work of the Ministry of National Defense, did not take any official action at that time in response to the statement of Antoni Macierewicz.

${ }^{6}$ During the discussion at the specially convened meeting that preceded the formulation of the Committee's statement (everything took place within one day), there were demands that the problem of Antoni Macierewicz's statement be dealt with by the Parliamentary Committee for Special Affairs, which was also the case - the explanations were considered on August 30, 2006, i.e., almost a week later, although Paweł Zalewski claimed on August 24,2006 that the matter had already been discussed there, probably in "various matters" - the Committee's agenda did not include this matter as a separate issue. The official item about Antoni Macierewicz's statement appeared on August 30, 2006 (see: Komisja do Spraw Służb Specjalnych, 2007). 
in the Merabishvili vs. Georgia case) - the temporary arrest of the former Prime Minister of Georgia and sentencing him to 5 years in prison (Merabishvili..., 2017). The position itself was adopted 17 days after the publication of the verdict, i.e., its publication influenced the deputies. Its adoption was preceded by a longer debate combined with listening to the information of Undersecretary of State in the Ministry of Foreign Affairs Bartosz Cichocki on Polish-Georgian relations, problems with prosecution of the opposition in Georgia (Pelny zapis..., 2017). From the point of view of the message's construction, the Merabishvili case was highlighted only in the last paragraph, earlier supporting Georgia's pro-EU and Euro-Atlantic aspirations and highlighting the $25^{\text {th }}$ anniversary of the renewal of Polish-Georgian relations (Stanowisko Komisji Spraw Zagranicznych..., 2017). Deputies took a long time to consider how to reconcile maintaining relations with simultaneous reference to political problems in the country. In the analyzed case, it is worth noting a frequent aspect that was raised in the committee's debate, that the rank-and-file members were informed about the committee's initiative itself during its deliberations, they did not know the content of the pushed document. It was usually the result of the work of one of the members or was prepared by the Bureau.

Analyzing the activity in individual terms it is not possible to draw farreaching conclusions that the formulation of positions disappears or develops in specific terms, but it is necessary to look more broadly. It is true that no statement of position was formulated in the $7^{\text {th }}$ term, but this term was exceptional in its character, as no resolution was formulated during it, and there was only one legislative initiative of the committee on Belarus (which was finally submitted as a project of the Presidium of the Sejm and adopted by acclamation at the $9^{\text {th }}$ Session of the Sejm on March 2, 2012). For research purposes, it may be assumed that the opinions of the committee of a potentially international character were to a large extent expressed as a contribution to the preparation of the resolutions of the Sejm prepared during this term of the Sejm, as the committee dealt with the drafts adopted by the Sejm later both on the protection of Christians in the world (twice), as well as with the issue of the situation of Polish schools in Lithuania?.

7 In the $6^{\text {th }}$ term of the Sejm (2007-2011) as many as seven statements were prepared, of which three related to Belarusian affairs, two to the Polish minority in Lithuania, and one to Georgia. There was also a statement on the circumstances of General Władysław Sikorski's death, which was exceptionally published also in English. A similar tendency can be seen in the case of the $5^{\text {th }}$ term - four 
Generally, the Committee's statements expressed commentary, concern, or reaction to important international events, but in the vast majority they concerned the most important directions for Polish foreign policy (Belarus, the position of the Polish minority in Lithuania, the political situation in the Caucasus), and the Committee's work harmonized with or complemented the actions of the Ministry of Foreign Affairs, rarely mobilizing it for intensive work.

Another possibility of action are the initiatives of committees - the rarely used possibility of a parliamentary committee to submit a bill by the committee (Art. 32 of the Rules of Procedure of the Sejm) ${ }^{8}$ or a resolution of the Sejm arising from Art. 33 of these Rules. The Foreign Affairs Committee happened to submit, for example, A Draft Resolution on Establishing the Parliamentary Assembly of the Republic of Poland and the Republic of Moldova, on May 25, 2011, or A Draft Resolution on Recent Developments in Georgian-Russian Relations and the Territorial Integrity of Georgia, on December 14, 2006, or A Draft Resolution on Parliamentary Elections in Iraq, on December 16, 2005. They gained the approval of the chamber and were adopted.

The issues cited were a voice in matters important to the state: strengthening of Poland's role in Moldova at the time of attempts to attract that country's elite to the European Union and limit Russian influence, support for Georgia's territorial integrity, or a comment on the parliamentary elections in Iraq - at that time a Polish military contingent was still stationed there and Poland was a country engaged in the region, and in 2016, an important initiative of a resolution on Christians was taken together with the Justice and Human Rights Committee.

An important instrument in exercising the control function, but also in taking up important and urgent matters that are of interest to the Polish foreign policy or should be of interest to the Polish Ministry of Foreign Affairs, are the desiderata, which we can define as wishes/postulates addressed most often in the case of the Foreign Affairs Committee to the Ministry of Foreign Affairs or the Council of Ministers, to which the institution usually has 30 days to respond, but is not obliged to implement the desiderata. Sometimes there is a combined desideratum, common to two or more committees, such as, for example, in 2016

positions, but apart from Iran also on elections in Abkhazia or Belarus, and it should be noted that due to the shortening of the work of the parliament the term lasted only two years.

${ }^{8}$ In its tradition, extending beyond the timeframe adopted in this publication, the committee has a legislative initiative on the Foreign Service Act, which was subsequently passed by the Sejm, but rejected by the Senate in 2001 (see: Dudek, 2013). The Sejm passed a motion to reject the Senate's resolution and it went into force after being signed by the president. 
(Dezyderat $n r 2 / 1 / 1 \ldots, 2016$ ), which is intended to strengthen the postulated issue, and in this particular case concerned the tasks posed to three committees: foreign affairs, education, and maintaining communication with Poles abroad. It concerned the critical situation of Polish educational institutions in Vilnius a larger number of entities strengthens the message.

In the political practice of many previous terms of office, after quite intensive periods of 1997-2005 (when 14 desiderata were formulated), in 2005-2007 three were adopted, two of which concerned Belarus, the same in 2007-2011, in 2011-2015 none was formulated, and in 2015-2019 again two - regarding education of Poles in Lithuania and financing of development policy.

We can speak of two types of desiderata (due to author's own typology):

- interventional - when the aim is to force/strengthen the government's or foreign ministry's response to a specific issue that the committee members care about. An example is the desideratum in defense of Abdul Rahman, an Afghan citizen urged to abandon Christianity. The desideratum states that "religious freedom should be the foundation of an international and social order that protects human rights" (Petny zapis..., 2006). The issue of religious freedom within the committee's work recurs throughout the post-1989 period, regardless of the political forces in power (Góra, Łabędź, Pochyły, 2019, pp. 105-154). Other examples include the already cited aspects related to the education of Poles in Lithuania.

- supportive - in situations of disagreements between the Ministry of Foreign Affairs and the Minister of Finance regarding obtaining more budget funds for foreign policy (membership fees in international organizations or development policy, including exerting pressure to maintain the Polish government's financing of Belsat TV - supporting in 2017 a request for financing the activities of this TV; in the end, an additional 20 million was transferred from the state budget for this purpose, which was considered appropriate, and the response to the request was accepted). The phenomenon of limited funds is a permanent feature after 1989 and has been the cause of political disputes and deputies' interventions in the Ministry of Finance in earlier periods (e.g., in 2001-2005), especially due to Poland's failure to pay its membership fees in international organizations on time. This was explained in 2017 by Civic Platform's President Schetyna when he cut off a discussion between one of the deputies and the Undersecretary of State at the Ministry of Foreign Affairs about ambiguous signals from the Ministry of Finance about the transfer of additional funds: "I will answer 
you, deputy. I know how it was in the earlier period, because the trouble with contributions is not a new story. This problem went from year to year, so to speak. At the moment I am also talking about the period of our government, when we had very serious budget problems. I understand that the situation will now normalize. Mr. Kamiński, the thing is very simple: you say 'fine' to the request made, but you do not send the money. That is what the ambiguous answer is. That is my experience" (Petny zapis..., 2017). The theoretical question, admonishing the Ministry of Foreign Affairs about an issue, in fact is not to force its actions, but to support the legislature granted to the executive power in an inter-ministerial trial of strength, and it happened with the approval of all political forces.

The last aspect, which is important, are the draft resolutions addressed to the Committee - adopted on important international issues. During a full term of office, there are about a dozen of them on average, which are referred to the Committee. The Committee does not undertake work on the vast majority of them. As a rule, only those issues are considered which have a non-protocol political consensus, are not considered harmful for the image of Poland or their creation is pushed by a deputy known to the committee, often a member of the committee, sometimes their creation is a request from the Speaker of the Sejm. For example, in the final report on the activities of the Foreign Affairs Committee for 2011-2015, Chairman Robert Tyszkiewicz showed that the Committee received 22 drafts, of which four were passed, including two on issues related to religious freedom (Sprawozdanie Komisji Spraw Zagranicznych, Czesść opisowa, 2015, pp. 7-8). The two additionally mentioned resolutions dealt with the issue of Polish schools in Lithuania and the situation in Belarus, i.e., they were important from the point of view of the Polish community and Polish interests in the region, as well as they expressed the personal interests of Chairman Tyszkiewicz, who has been involved in the Belarusian issue for years ${ }^{9}$.

9 In the years 2005-2007, there were resolutions on the Polish-American Youth Exchange Program, evaluation of presidential elections in Belarus, escalation of violence caused by racism and homophobia in Europe, condemnation of the European Parliament initiative to finance embryo and stem cell research by the EU, support for the position of the Polish Government on the treaty establishing a Constitution for Europe, negotiations of the new EU Treaty. In view of the incomplete term and political practice, as many as $35.2 \%$ of the submitted draft resolutions were passed by the Sejm after work in committee (6 out of 17). 


\section{CONCLUSIONS}

In the analyzed period, the Foreign Affairs Committee of the Sejm took an active stance within the framework of its constitutional, statutory and regulatory competencies. The vast majority of interest in the formulation of statements, desiderata or resolutions from the geographical point of view was directed towards the affairs of Belarus (also in the form of debates, which did not end with formulating an official statement), interventions in defense of Poles in Lithuania, evaluation of political processes in the Caucasus, as well as initiatives in defense of religious freedom in the world.

The geographic nature of the committee's interests overlapped with the activities undertaken by the Ministry of Foreign Affairs, being a supporting, complementary element, and this is how the analysis of the positions or decisions should be assessed. Also the scope of budget support, especially in the $8^{\text {th }}$ term, but also, e.g., in the years 2001-2005 (not covered by the analysis), points to conclusions about the processes common for various political forces and a certain symbiosis between the legislative power represented by the commission and the executive power in the area of foreign policy (the Ministry of Foreign Affairs). It cannot be overestimated that over the years members of the committee have been foreign ministers (Włodzimierz Cimoszewicz, Anna Fotyga, Witold Waszczykowski), also previously serving as chairman of the committee (in the $1990^{\text {s }}$ - Bronisław Geremek, but also Grzegorz Schetyna, or Zbigniew Rau from 2020). This process of interpenetration in posts is also an important reason why ambassadors or politicians engage in intensive parliamentary dialogue - the interlocutor may in the future hold an important position in Polish diplomacy or in the government, thus the previously developed relationship is invaluable.

It is noteworthy that, irrespective of its political background, the committee provided support to the ministry in emergency situations when it expected it, and that the political situation in Belarus is the most frequently undertaken foreign policy direction, which is fully justified given the close proximity, the size of the Polish minority in this country, and the potential use of the territory in the event of Russian aggression against Poland. 


\section{REFERENCES:}

Badatya, S. (2019). Parliament and Foreign Policy Decision Making in India: Extent, Instruments and Impediments. Journal of Governance \& Public Policy, 9(2), 2-15.

Dezyderat nr 2/1/1 Komisji Łączności z Polakami za Granica, Komisji Spraw Zagranicznych oraz Komisji Edukacji, Nauki i Młodzieży do Rady Ministrów w sprawie krytycznej sytuacji placówek oświatowych z polskim językiem nauczania w Wilnie uchwalony na wspólnym posiedzeniu w dniu 18 marca 2016 r. (2016). [Desideratum No. 2/1/1 of the Committee on Liaison with Poles Abroad, the Committee on Foreign Affairs and the Committee on Education, Science and Youth to the Council of Ministers on the Critical Situation of Educational Institutions with Polish Language of Instruction in Vilnius Adopted at a Joint Meeting on 18 March 2016]. Retrieved from: http://orka.sejm.gov.pl/opinie8.nsf/nazwa/enm_d1/\$file/enm_d1.pdf.

Dudek, A. (2013). Kompetencje inicjatywne sejmowej Komisji Spraw Zagranicznych na przykładzie uchwalenia ustawy o służbie zagranicznej. Wrocławskie Studia Politologiczne, 14, 7-19.

Dudek, A. (2019). Decydowanie w polskiej polityce zagranicznej (1992-1997). Perspektywa organizacyjna i biurokratyczna. Warszawa: Wydawnictwo Naukowe SCHOLAR.

Habowski, M. (2019). Funkcje kontrolna i kreacyjna Sejmu w kształtowaniu polityki zagranicznej Rzeczypospolitej Polskiej w latach 1997-2004. Warszawa: Wydawnictwo Uniwersytetu Warszawskiego.

Jaskiernia, J. (2004). Charakter prawny i funkcje Komisji Spraw Zagranicznych Sejmu RP. Polski Przeglad Dyplomatyczny, 22(6), 25-130.

Jaskiernia, J. (2013). Dyplomacja parlamentarna - nowe oblicze dyplomacji? In: B. Surmacz (Ed.). Nowe oblicza dyplomacji. Warszawa: Wydawnictwo Naukowe SCHOLAR.

Juchniewicz, J. (2013). Instrumenty realizacji funkcji kontrolnej Sejmu - próba oceny skuteczności. Przegląd Prawa Konstytucyjnego, 1, 15-32. DOI: 10.15804/ ppk.2013.01.01.

Kesgin, B., \& Kaarbo J. (2010). When and How Parliaments Influence Foreign Policy: The Case of Turkey's Iraq Decision. International Studies Perspectives, 11(1), 19-36. DOI: 10.1111/j.1528-3585.2009.00390.x.

Komisja do Spraw Służb Specjalnych (2007, September 27). Posiedzenie nr 79. Retrieved November 20, 2020 from: http://orka.sejm.gov.pl/SQL.nsf/Main5?OpenForm\&KSS. Kruk, M. (2008). Funkcja kontrolna Sejmu RP. Warszawa: Wydawnictwo Sejmowe.

Kuciński, K. (2017). Status prawny komisji sejmowych jako podmiotów kontroli działalności rządu. Przegląd Sejmowy, 1, 9-36.

Łuszczuk, M. (2015). Zaangażowanie międzynarodowych instytucji parlamentarnych z Europy Północnej we współpracę w regionie Arktyki. In: Ł. Fijałkowski, \& E. Stadtmüller (Eds.). Normy, wartości i instytucje we wspótczesnych stosunkach międzynarodowych. Vol. 2 (pp. 139-159). Warszawa: Polski Towarzystwo Studiów Międzynarodowych \& Wydawnictwo Rambler. 
Malamud, A., \& Stavridis, S. (2011). Parliaments and Parliamentarians as International Actors. In: B. Reinalda (Ed.). The Ashgate Research Companion to Non-State Actors (pp. 101-115). London and New York: Routledge.

Mały Rocznik Statystyczny Polski (2020). Warszawa: GUS.

Merabishvili przeciwko Gruzji (wyrok - 28 listopada 2017 r., Wielka Izba, skarga nr 72508/13 - przyjęta do rozpatrzenia na wniosek rzadu) (2017). Retrieved from: https://www.hfhr.pl/wp-content/uploads/2017/12/Omowienie_orzeczenia_Merabishvili_przeciwko_Gruzji.pdf.

Onderco, M. (2018). Parliamentarians in Government Delegations: An Old Question Still Not Answered. Cooperation and Conflict, 53(3), 411-428. DOI: $10.1177 / 0010836717737571$.

Pełny zapis przebiegu posiedzenia Komisji Spraw Zagranicznych (nr 48) z dnia 24 sierpnia 2006 r. (2006). [Full Transcript of the Meeting of the Committee on Foreign Affairs (No. 48) of August 24, 2006]. Retrieved from: http://orka.sejm.gov.pl/Biuletyn.nsf/ 0/19EE8641B8112679C12571F8002A0405/\$file/0102105.pdf.

Pełny zapis przebiegu posiedzenia Komisji Spraw Zagranicznych (nr 130) z dnia 7 maja 2014 r. (2014). [Full Transcript of the Meeting of the Committee on Foreign Affairs (No. 130) of May 7, 2014]. Retrieved from: https://orka.sejm.gov.pl/zapisy7.nsf/0/4 294F34913E51DD7C1257CDD004B5B6F/\%24File/0323607.pdf.

Pełny zapis przebiegu posiedzenia Komisji Spraw Zagranicznych (nr 91) z dnia 14 grudnia 2017 r. (2017). [Full Transcript of the Meeting of the Committee on Foreign Affairs (No. 91) of December 14, 2017]. Retrieved from: https://orka.sejm.gov.pl/zapisy8. nsf/0/706316FA484A7E64C1258205004654BE/\%24File/0269008.pdf.

Podgórzańska R. (2006). Rola i znaczenie Sejmowej Komisji Spraw Zagranicznych po 1989 roku. ACTA POLITICA NR 18. ZESZYTY NAUKOWE.

Podgórzańska, R. (2007). Działalność sejmowej Komisji Spraw Zagranicznych (19892005): wybrane problemy. Warszawa: Wydawnictwo Sejmowe.

Raunio, T., \& Wagner, W. (2017). Towards Parliamentarisation of Foreign and Security Policy? West European Politics, 40(1), 1-19. DOI: 10.1080/01402382.2016.1240411. Regulamin Sejmu RP (tekst jednolity M.P. 2012 poz. 32 z późn. zm.) (2012). [Rules of Procedure of the Sejm]. Retrieved from: http://www.sejm.gov.pl/prawo/regulamin/ kon7.htm.

Sikorski, R. (2018). Polska może być lepsza. Kraków: Znak.

Sprawozdanie Komisji Spraw Zagranicznych z działalności w VII kadencji Sejmu (2011-2015), Część informacyjno-statystyczna (spis tabel) (2015). Warszawa. Tabela 18 - Wizyty delegacji parlamentarnych oraz przedstawicieli wybranych instytucji i organizacji międzynarodowych [Report of the Committee on Foreign Affairs on Activities in the $7^{\text {th }}$ Term of the Sejm (2011-2015), Information and Statistical Part (List of Tables). Warsaw, Table 18 - Visits of Parliamentary Delegations and Representatives of Selected International Institutions and Organizations].

Retrieved from: http://orka.sejm.gov.pl/opinie7.nsf/nazwa/spis_tabel_SZA/\$file/ spis_tabel_SZA.pdf. 
Sprawozdanie Komisji Spraw Zagranicznych z działalności w VII kadencji Sejmu (2011-2015), Cześś opisowa (2015). [Report of the Committee on Foreign Affairs on the Activities of the $7^{\text {th }}$ Term of the Sejm (2011-2015), Narrative part]. Retrieved from: http://orka.sejm.gov.pl/opinie7.nsf/nazwa/opis_SZA/\$file/opis_SZA.pdf.

Sprawozdanie Komisji Spraw Zagranicznych $z$ działalności $w$ VIII kadencji Sejmu (2015-2019), Część informacyjno-statystyczna (spis tabel) (2019). Warszawa. Tabela 19 - Wizyty delegacji parlamentarnych oraz przedstawicieli instytucji i organizacji zagranicznych [Report of the Committee on Foreign Affairs on Activities in the $8^{\text {th }}$ Term of the Sejm (2015-2019), Information and Statistical Part (List of Tables), Warsaw. Table 19 - Visits of Parliamentary Delegations and Representatives of International Institutions and Organizations]. Retrieved from:

http://orka.sejm.gov.pl/opinie8.nsf/nazwa/tabela19_sza/\$file/tabela19_sza.pdf.

Stanowisko Komisji Spraw Zagranicznych w sprawie wypowiedzi Pana Antoniego Macierewicza, podsekretarza stanu w Ministerstwie Obrony Narodowej, przyjęte $w$ dniu 24 sierpnia 2006 roku (2006). [Statement of the Committee on Foreign Affairs...]. Retrieved from: http://orka.sejm.gov.pl/opinie5.nsf/nazwa/sza_ 0997/\$file/sza_0997.pdf.

Stanowisko Komisji Spraw Zagranicznych Sejmu Rzeczypospolitej Polskiej przyjęte na posiedzeniu w dniu 14 grudnia 2017 r. w sprawie stosunków polsko-gruzińskich (2017). [Statement of the Committee on Foreign Affairs of the Sejm of the Republic of Poland Adopted at Its Session of 14 December 2017 on Polish-Georgian Relations]. Retrieved from: http://orka.sejm.gov.pl/opinie8.nsf/nazwa/sza_sta276/\$file/ sza_sta276.pdf.

Surmacz, B., \& Kuczyńska-Zonik, A. (Eds.) (2019). Dyplomacja parlamentarna $w$ Europie Środkowej i Wschodniej w latach 2015-2019. IEŚ Policy Papers, 2. Lublin: Instytut Europy Środkowej.

Tayie, M.S., \& Dashti, I.M. (2018). Parliament and Foreign Policy-Making Process. Asian Social Science, 14(2), 165-172. DOI: 10.5539/ass.v14n2p165.

Wyjazdy zagraniczne przedstawicieli komisji. Tabela 17 (2015). [Foreign Departures by Committee Representatives. Table 17]. Retrieved from: http://orka.sejm.gov.pl/ opinie7.nsf/nazwa/tabela17_SZA/\$file/tabela17_SZA.pdf.

Wyjazdy zagraniczne przedstawicieli komisji. Tabela nr 18 (2019). [Foreign Departures by Committee Representatives. Table No. 18]. Retrieved from: http://orka.sejm.gov. pl/opinie8.nsf/nazwa/tabela18_sza/\$file/tabela18_sza.pdf.

Zaremba, J. (2018, September 14). Witold Waszczykowski: Niemcy postępuja złośliwie. Brutalnie pogwałcili oficjalny zakaz wjazdu do UE. Retrieved from: https://www. radiozet.pl/Radio/Z-zycia-Radia/Gosc-Radia-ZET.-Wirold-Waszczykowski-uBeaty-Lubeckiej.-14.09.2018. 